\title{
Cyathostomin larvae: presence on Brachiaria humidicola grass during the rainy and dry seasons of Brazil
}

\author{
Larvas de ciatostomíneos: disponibilidade em gramínea Brachiaria humidicola \\ nas estaçóes chuvosa e seca do Brasil \\ Claudia Navarro dos Santos ${ }^{1 *}$; Luciene Soares de Souza ${ }^{1}$; Vivian Suane de Freitas Vieira ${ }^{1}$; \\ Jairo Pinheiro ${ }^{2}$; Maria de Lurdes de Azevedo Rodrigues ${ }^{3}$
}

\author{
${ }^{1}$ Graduate Program in Veterinary Sciences, Animal Parasitology Dept., Federal Rural University of Rio de Janeiro - UFRRJ \\ ${ }^{2}$ Postgraduate Program on Veterinary Sciences - CPGCV, Physiological Sciences Dept., \\ Federal Rural University of Rio de Janeiro - UFRRJ \\ ${ }^{3}$ Postgraduate Program on Veterinary Sciences - CPGCV, Animal Parasitology Dept., \\ Federal Rural University of Rio de Janeiro - UFRRJ \\ Received April 07, 2011 \\ Accepted July 132011
}

\begin{abstract}
The presence of cyathostomin larvae is directly associated to climatic conditions of each region. This study aimed to evaluate the ecology of infective larvae on Brachiaria humidicola during the dry and rainy seasons from October 2007 to September 2008 in a tropical region, Rio de Janeiro state, southeastern Brazil. Stools were collected from the rectum of horses naturally infected with cyathostomins at the beginning of the rainy season (October to March) and dry season (April to September). They were divided into four samples of $500 \mathrm{~g}$ and deposited on a grass patch of B. humidicola. Seven days later and every 15 days thereafter samples of feces and grass were collected and processed by the Baermann technique. The mean number of larvae recovered from the grass varied according to the season, with greater recovery of larvae during the peak of the dry season $\left(14,700 \mathrm{~L}_{3} \cdot \mathrm{kg}^{-1} \mathrm{DM}\right)$. There was a statistically significant difference between $\mathrm{L}_{3}$ recovered from feces and grass, but not between $\mathrm{L}_{3}$ recovered from the grass base and apex. These results show that the region's climate favors the development and survival of infective cyathostomin larvae throughout the year, with a greater number of larvae during the dry season.
\end{abstract}

Keywords: Infective larvae, wet and dry seasons, Brachiaria humidicola, cyathostomin.

\section{Resumo}

A disponibilidade de larvas de ciatostomíneos está diretamente relacionada com as condições climáticas de cada região. Para avaliar o comportamento das larvas infectantes nos períodos seco e chuvoso em gramínea Brachiaria humidicola, realizou-se um estudo, no período de outubro/2007 a setembro/2008, na regiāo da Baixada Fluminense, RJ, de clima tropical. Amostras de fezes foram coletadas diretamente do reto de equinos naturalmente infectados por ciatostomíneos, no início do período chuvoso (outubro a março) e seco (abril a setembro), divididas em quatro amostras de $500 \mathrm{~g}$ e depositadas em um canteiro formado por gramínea $B$. humidicola. Sete dias após o depósito e, posteriormente, a cada 15 dias, amostras de fezes e gramíneas, foram coletadas às 8 horas e processadas pela técnica de Baermann. O número médio de larvas recuperadas da gramínea variou conforme os períodos, ocorrendo maior recuperação no ápice do período seco $\left(14.700 \mathrm{~L}_{3} \cdot \mathrm{kg}^{-1}\right.$. MS). Diferença significativa ocorreu entre a contagem de $\mathrm{L}_{3}$ recuperadas das fezes e gramínea e não significativa entre as de $\mathrm{L}_{3}$ recuperadas nas duas alturas da gramínea. Concluiu-se que as condiçôes climáticas da região favorecem o desenvolvimento e a sobrevivência de larvas infectantes de ciatostomíneos durante todo o ano, com maior disponibilidade no período seco.

Palavras-chave: Larvas infectantes, períodos chuvoso e seco, Brachiaria humidicola, ciatostomíneos.

\footnotetext{
${ }^{*}$ Corresponding author: Claudia Navarro dos Santos

Animal Parasitology Department,

Federal Rural University of Rio de Janeiro - UFRRJ,

BR 465, Km 7, CEP 23890-000, Seropédica, RJ, Brazil

e-mail: claudianavarro_parasito@yahoo.com.br
} 


\section{Introduction}

Cyathostomin infection of horses occurs due to ingestion of infective larvae while grazing (LANGROVÁ et al., 2003). Climatic conditions influence the development and survival of cyathostomins affecting parasite loads (BEZERRA et al., 2007; QUINELATO et al., 2008). Thus, there is a need to know the epidemiology of these parasites and their interaction with the host to establish effective control strategies. Studies of the prevalence of cyathostomin larvae in pastures using different grasses have been performed in Brazil by Bezerra et al. (2007) (Tifton 85), Couto et al. (2009) (Coast cross) and Santos et al. (2011) (Brachiaria humidicola). It is essential to find alternative control methods to minimize the use of anthelmintics due to cyathostomin resistance to different groups of chemicals. Knowledge about the biology and influence of environmental factors on the development and survival of cyathostomins can help their control (RAMSEY et al., 2004). This study aimed to evaluate the ecology of cyathostomin larvae in Brachiaria humidicola grass during the rainy and dry seasons in Seropédica, state of Rio de Janeiro, southeastern Brazil.

\section{Materials and Methods}

\section{Local}

An experimental plot $(11.5 \times 1.0 \mathrm{~m})$ was set up at the W.O. Neitz Parasitological Research Station of the Helminthology Laboratory in Seropédica, in the Baixada Fluminence region of the State of Rio de Janeiro ( $22^{\circ} 41^{\prime} \mathrm{S}$ and $43^{\circ} 41^{\prime} \mathrm{W}$, altitude $33 \mathrm{~m}$ ). The plot was part of a pasture not previously used for grazing containing Brachiaria humidicola. The local climate is humid tropical according to the Köppen classification (PELL et al., 2007). The experimental area was surrounded with barbed wire to prevent access and contamination from other animals.

\section{Procedures}

The experiment was conducted from October 2007 to September 2008 to assess the presence of cyathostomin larvae on grass and feces. At the beginning of the rainy and dry seasons, stools were collected directly from the rectum of 15 horses naturally infected aged 1 to 3 years. The fecal matter was processed by the techniques described by Gordon and Whitlock (1939) and Roberts and O'Sullivan (1950) for egg counts (number of eggs per gram of feces, EPG) and infective larvae $\left(\mathrm{L}_{3}\right)$ recovery, respectively. The fecal material collected was divided into four samples of $500 \mathrm{~g}$ each and deposited in the plot and examined during 12 months. Stool (approx. $2 \mathrm{~g}$ ) and grass samples around the site where the four fecal samples were deposited were collected seven days later and every fifteen days afterward, always at 8:00 AM for recovery of larvae from the grass, the samples were divided into base $(\mathrm{GB}=0-10 \mathrm{~cm})$ and apex $(\mathrm{GA}=10-20 \mathrm{~cm})$. Stool samples were weighed and grass was processed by Bezerra et al. (2007) technique. Stool and grass samples were immersed into water at room temperature and left to rest for 24 hours, after which a $5 \mathrm{~mL}$ solution was collected containing cyathostomin larvae, which were identified and counted. The stool and grass samples were incubated at $75^{\circ} \mathrm{C}$ for 48 hours to obtain dry matter (DM). Counting and identification of the recovered larvae was based on Bevilaqua et al. (1993) description. Climate data were provided by the weather station at the Seropédica Agricultural Ecology Station (INMET/PESAGRO) in Rio de Janeiro. The results were analyzed by the nonparametric Kruskal-Wallis test (ZAR, 1999) for comparison of unpaired means $(\alpha=5 \%)$ using the GraphPad InStat v. 3.00 and GraphPad Prism v. 3.02 programs (Prism, Inc.) and expressed as mean \pm standard error. $\mathrm{L}_{3}$ recovery data were converted into percentages.

\section{Results}

\section{Meteorological data}

Figure 1 shows the variations in rainfall and average air and soil temperatures during the study period. There was little variation in air and soil temperatures. The maximum average air temperature was $27.2^{\circ} \mathrm{C}$ in December and the minimum was $20.6^{\circ} \mathrm{C}$ in July. The highest average soil temperature was $26.5^{\circ} \mathrm{C}$ in December and the lowest was $18^{\circ} \mathrm{C}$ in September. Rainfall varied between the different periods studied, with the highest average recorded in February $(188.9 \mathrm{~mm})$ and lowest in June $(16.0 \mathrm{~mm})$.

\section{Count of infective cyathostomin larvae (L3) on grass and in feces}

There were 2,608 and 2,283 EPG of the fecal masses deposited at the beginning of the rainy and dry seasons, respectively. Figure 2 shows the dynamic of recovery of infective cyathostomin larvae from the grass (apex and base). The largest number of larvae was recovered from the grass during the dry season, with a peak in April of $14,700 \mathrm{~L}_{3} \cdot \mathrm{kg}^{-1} \mathrm{DM}$ in the grass apex.

In feces, the total number de larvae recovered was higher during the dry season (Figure 3). There was a significant difference $(p<0.05)$ in the number of larvae in the stool samples between the two grass heights (GA and GB) during the same season.

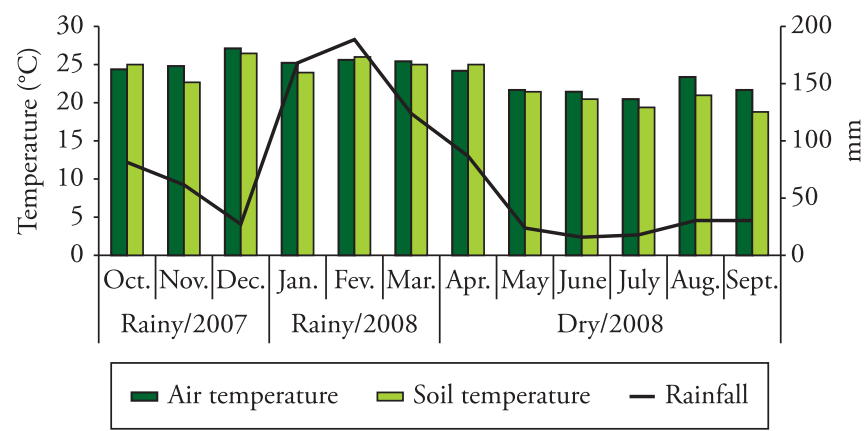

Figure 1. Total rainfall $(\mathrm{mm})$ and average air and soil temperatures $\left({ }^{\circ} \mathrm{C}\right)$ in Seropédica, RJ, Brazil, between October 2007 and September 2008. 


\section{Percentage recovery of infective larvae $\left(L_{3}\right)$ during the dry and rainy seasons}

Figure 4 shows the percentage of $\mathrm{L}_{3}$ larvae recovered from the grass (base and apex) and feces. It can be seen that during the dry period the percentage of larvae in the feces was higher. In both periods the fecal mass was a reservoir of larvae, with little variation in the percentage between the dry and rainy seasons.

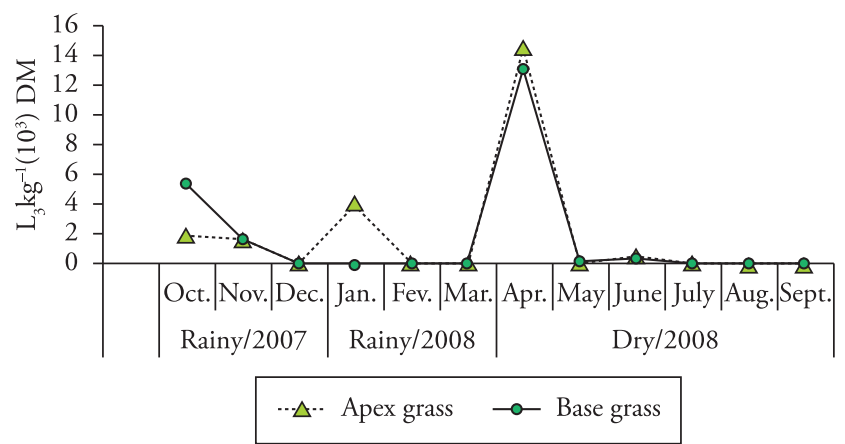

Figure 2. Average number of cyathostomin $\mathrm{L}_{3}$ larvae recovered from grass samples in the period from October 2007 to September 2008 in Seropédica, RJ, Brazil. Deposits of fecal masses: wet season July 28, dry season March 25.

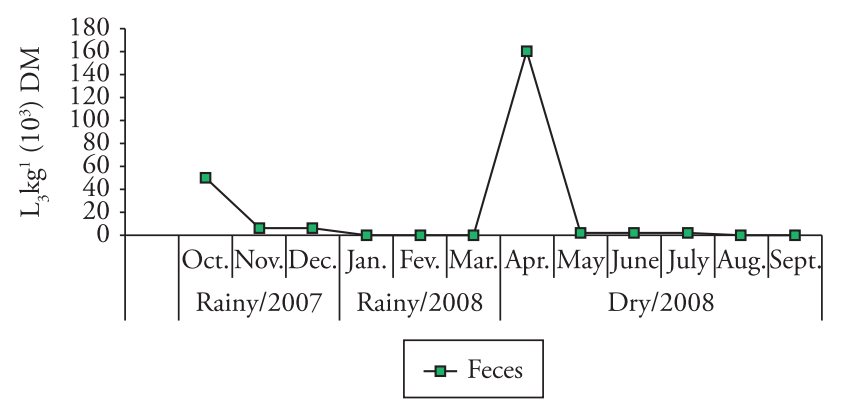

Figure 3. Average number of cyathostomin larvae recovered from feces from October 2007 to September 2008. Deposit of fecal masses: wet season July 28, dry season March 25.

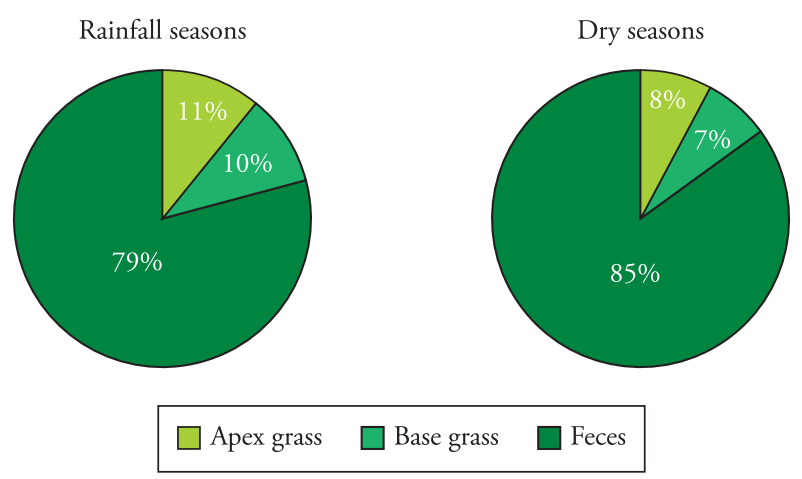

Figure 4. Percentage of cyathostomin $\mathrm{L}_{3}$ larvae recovered during the rainy and dry seasons in Seropédica, RJ, Brazil. (GA = grass apex; $\mathrm{GB}=$ grass base).

\section{Discussion}

The average temperature ranges between 23.7 and $27.2^{\circ} \mathrm{C}$ during the rainy season and 20.2 to $24.5^{\circ} \mathrm{C}$ during the dry season in Seropédica lies within the range of 10 to $33^{\circ} \mathrm{C}$, considered excellent for the development of eggs and larvae of equine cyathostomes reported in other studies (OGBOURNE, 1972; MFITILODZE; HUTCHINSON, 1987). The highest EPG count was seen in the fecal mass deposited at the beginning of the rainy season, which favors free-living stages contributing to pasture contamination. Higher average recovery of $\mathrm{L}_{3}$ from the stool $\left(165,400 \mathrm{~kg}^{-1} \mathrm{DM}\right)$ and grass samples $\left(14,700\right.$ and $13,200 \mathrm{~L}_{3} \cdot \mathrm{kg}^{-1} \mathrm{DM}$ in the GA and $\mathrm{GB}$, respectively) during the dry season was probably due to ideal temperature conditions and low rainfall. These findings agree with those reported by Langrová et al. (2003), Bezerra et al. (2007), Nielsen et al. (2007), Quinelato et al. (2008) and Santos et al. (2011). Fecal masses play an important role in the development of eggs and larvae, acting as reservoirs for larvae, as observed by Mfitilodze and Hutchinson (1987), Uhlinger (1991), Bezerra et al. (2007) and Santos et al. (2011). With adequate humidity and temperature, horses can become infected immediately after rainfall, but these animals in this area are more exposed to infection during dry than heavy rainfall periods (BEZERRA et al., 2007; QUINELATO et al., 2008; COUTO et al., 2008; COUTO et al., 2009; RODRIGUES et al., 2008). The environmental conditions of the study area favor the development of infective cyathostomin larvae, i.e., $\mathrm{L}_{3}$ were present in the pasture during both periods studied. Therefore, prevention and control methods are needed to reduce the number of larvae present in pastures thoroughout the year. The type of grass can also affect the number of larvae recovered. Other studies with different grasses in the same study area reported a lower number of larvae recovered from Coast-cross and Tifton 85 pastures (BEZERRA et al., 2007; COUTO et al., 2008; COUTO et al., 2009; QUINELATO et al., 2008; SANTOS et al., 2011) than from Brachiaria humidicola in our study. Pastures are more fibrous and flattened during the dry season and, depending on the management, they can protect $\mathrm{L}_{3}$ against temperature changes and evaporation (BRADY; WEIL, 1999), providing an ideal microclimate for a prolonged survival. Similar to this study, Hutchinson et al. (1989) did not find a correlation between the number of $\mathrm{L}_{3}$ recovered from pasture and rainfall.

\section{Conclusion}

The climatic conditions of the region studied favor the development and survival of infective cyathostomin larvae throughout the year, with a higher number of larvae seen during the dry season (April to September). Compared with other grasses studied in the region, Brachiaria humidicola is the least suitable for feeding horses due to a high number of infective cyathostomin larvae recovered.

\section{Acknowledgements}

We thank the Graduate Program in Veterinary Sciences (CPGCV) of Universidade Federal Rural do Rio de Janeiro (UFRRJ), the Brazilian Federal Agency for Support and Evaluation 
of Graduate Education (CAPES) and the National Council for Scientific and Technological Development (CNPq) for their financial support; and Seropédica Agricultural Weather Station (INMET/ PESAGRO) for providing the meteorological data for this study.

\section{References}

Bevilaqua CML, Rodrigues MLA, Concordet D. Identification of infective larvae of some common nematode strongylids of horses. Rev Med Vet 1993; 144(12): 989-995.

Bezerra SQ, Couto MCM, Souza TM, Bevilaqua CML, Anjos DHS, Sampaio IBM, et al. Ciatostomíneos (Strongylidae-Cyathostominae) parasitas de cavalos: Ecologia experimental dos estágios pré-parasíticos em gramínea tifton 85 (Cynodon spp. cv. Tifton 85) na baixada Fluminense, RJ, Brasil. Parasitol Latinoam 2007; 62 (1-2): 27-34.

Brady NC, Weil, RR. Te nature and properties of soils. $12^{\text {nd }} \mathrm{ed}$. New Jersey: Prentice Hall; 1999. 881 p.

Couto, MCM, Quinelato S, Santos CN, Souza LS, Sampaio IBM, Rodrigues MLA. Environmental influence in Cyathostominae ecology. Vet Med 2008; 53(5): 243-249.

Couto MCM, Quinelato S, Souza TM, Santos CN, Bevilaqua CML, Anjos DHS, et al. Desenvolvimento e migração de larvas infectantes de ciatostomíneos (Nematoda:Cyathostominae) em gramínea coast cross (Cynodon dactylon) em clima tropical, na Baixada Fluminense, RJ, Brasil. Rev Bras Parasitol Vet 2009; 18(2): 31-37.

Gordon $\mathrm{HMCl}$, Whitlock AV. A new technique for counting nematode eggs in sheep faeces. J Coun Scient Ind Res Aust 1939; 12(1): 50-52.

Hutchinson GW, Abba SA, Mfitilodze MW. Seasonal translation of equine strongyle infective larvae to herbage in tropical Australia. Vet Parasitol 1989; 33(3-4): 251-263. http://dx.doi.org/10.1016/03044017(89)90135-0

Langrová I, Jankovská I, Borovský M, Fiala T. Effect of climatic influences on the migrations of infective larvae of Cyathostominae. Vet Med Czech 2003; 48(1-2): 18-24.

Mfitilodze MW, Hutchinson GW. Development and survival of freeliving stages of equine strongyles under laboratory conditions. Vet Parasitol 1987; 23(1-2): 121-133. http://dx.doi.org/10.1016/03044017(87)90030-6
Nielsen MK, Nielsen MK, Kaplan RM, Thamsborg SM, Monrad J, Olsen, SN. Climatic influences on development and survival of free-living stages of equine strongyles: Implications for worm control strategies and managing anthelmintic resistance. Vet J 2007; 174(1): 23-32. PMid:16815051. http://dx.doi.org/10.1016/j.tvjl.2006.05.009

Ogbourne CP. Observations on the free-living stages of strongylid nematodes of horse. Parasitology 1972; 64: 461-477. http://dx.doi. org/10.1017/S0031182000045534

Peel MC, Finlayson BL, Mcmahon TA. Updated world map of the Köppen-Geiger climate classification. Hydrol Earth Syst Sci 2007; 11: 1633-1644.

Quinelato SB, Couto MCM, Ribeiro BC, Santos CN, Souza LS, Anjos DHS, et al. The ecology of horse Cyathostomin infective larvae (NEMATODA-CYATHOSTOMINAE) in tropical southeast Brazil. Vet Parasitol 2008; 153(1-2): 100-107. PMid:18329175. http://dx.doi. org/10.1016/j.vetpar.2008.01.027

Ramsey YH, Chistley RM, Matthews JB, Hodgkinson JE, McGoldrick J, Love S. Seasonal development of Cyathostominae larvae on pasture in a northern temperate region of the United Kingdom. Vet Parasitol 2004; 119(4): 307-318. PMid:15154595. http://dx.doi. org/10.1016/j.vetpar.2003.11.014

Roberts HS, O'Sullivan PS. Methods for egg counts and larval cultures for Strongyles infesting the gastro-intestinal tract of cattle. Aust J Agric Res 1950; 1(1): 99-102. http://dx.doi.org/10.1071/AR9500099

Rodrigues MLA, Couto MCM, Quinelato S, Santos CN, Souza LS, Sampaio IBM. Influência das condiçôes climáticas na migração e sobrevivência de larvas infectantes de ciatostomíneos em Brachiaria bumidicola, na baixada Fluminense do Rio de Janeiro, Brasil. Cienc Anim 2008; 18(1): 7-14.

Santos CN, Souza LS, Quinelato SB, Couto MCM, Pinheiro J, Rodrigues MLA. Seasonal dynamics of cyathostomin (Nematoda-Cyathostominae) infective larvae in Brachiaria humidicola grass in tropical southeast Brazil. Vet Parasitol 2011; 180(3-4): 274-278. PMid:21489693. http://dx.doi. org/10.1016/j.vetpar.2011.03.026

Uhlinger CA. Equine small strongyles: epidemiology pathology and control. Compend Contin Educ Pract Vet 1991; 13(5): 863-869.

Zar JH. Biostatistical Analysis. $4^{\text {nd }}$ ed. Upper Saddle River: Prentice Hall; 1999.663 p. 